\title{
STATE COLLAPSE AND REGIONAL CONTAGION IN SUB-SAHARA AFRICA: LESSONS FOR ZIMBABWE
}

\author{
James J. Hentz \\ Department of International Studies and Political Science \\ Virginia Military Institute
}

\section{Hollowing out the state}

State collapse is one of the most important security threats in Sub-Sahara Africa. The George W. Bush administration's National Security Strategy includes failed and failing states as a national security priority. ${ }^{1}$ The U.S. European Command, whose area of responsibility includes much of Sub-Sahara Africa, are "concerned about ungoverned areas descending into chaos with terrorist and warlords...." 2 The United Nations is trying to restore order to numerous collapsed states in Africa. Nonetheless, while there are discernable patterns to state failure and collapse, not near enough attention has been paid to them. This is a problem, of course, primarily for Sub-Sahara Africa, but increasingly, as well, for the rest of the world that has interests in that continent. This essay will point out these patterns. It will briefly describe and explain state collapse in West Africa and in Central Africa. It will then use those patterns to discuss the possibility of collapse in Zimbabwe and the potential contagion effects for the southern African subcontinent.

Thus far, the contagion of state failure has been confined to West Africa, its epicenter in Liberia, and to Central Africa, centered on the Democratic Republic of Congo (DRC). It has left Liberia in ruin for more than a decade and spread to neighboring states and has triggered Africa's First World War in central Africa, estimated by the International Rescue Committee to have caused as many as three

The Bush administration has tied the problem of failed and weak states to its fight against terrorism. See, "The National Security Strategy of the United States," The White House: Washington, D.C. (September 2002). http://www.whitehouse.gov/nsc/nss.pdf.

Brian Whitmore, "US Forces in Europe Will Shift Some of Their Focus to Africa," 15 February, 2004, p.1. 
million deaths. ${ }^{3}$ Finally, lessons from West and Central Africa could be a harbinger for Zimbabwe and southern Africa.

Two factors contribute to state collapse and its contagion effect. One is an inside-out and the other an outside-in process. From the inside, successive rulers of what are now collapsed states weakened that state through neo-patrimonial rule. ${ }^{4}$ As Christopher Clapham argues, while we must not over-generalize, in Sub-Sahara Africa there are a "... distressingly large number of states in which acceptable political formulae have not been developed, and that remain vulnerable to collapse, or have actually collapsed." ${ }^{5}$ The states were not only unable to develop a stable political system but lacked administrative capacity to govern effectively and to ignite sustainable economic development. The weakness of the Africa state was most obvious in the periphery of those states. Thus, while the core of the state, typically centered on the capital, weakens through mismanagement and political failure, pressure from the periphery force in on that center and caused state collapse.

Political scientists labeled Sub-Saharan African states quasi states, ${ }^{6}$ because, while they had a patina of statehood (such as a seat at the U.N) and formal recognition of their sovereignty (such as by the Organization of African Unity (OAU)) they were not fully functional states. They had international legitimacy but little or no domestic legitimacy. Over time, successive rulers of these states used their power and position for the advancement and enrichment of themselves and a small coterie of clients, often defined by tribal or ethnic affinity. For instance, public corporations, or parastatals, were used to rig markets to gather rents for the rulers and their clients. ${ }^{7}$

This inside-out process of state decay gathers most of the attention in the press and in academic and policy studies, but it is only part of the story. There is an important regional dimension - an historically contingent outside-in process that has contributed to the development of dysfunctional states, their collapse, and regional instability.

San Francisco Chronicle, 9 June 2002, "Civil War in Africa," Adam Hochschild.

The work of William Reno clearly outlines this argument. See, Warlord Politics and African States (Boulder: Lynne Rienner Publishers, 1988). For an explanation of how partrimonial systems work see, Christopher Clapham, ed. Private Patronage and Public Power (New York: St. Martin's Press, 1982).

$5 \quad$ Christopher Clapham, "Rethinking African States," Africa Security Review Vol. 10, No. 3 (2001). http://www.iss.co.za/Pubs/ASR/10No3/Clapham.html.

$6 \quad$ Robert Jackson, Quasi-States: Sovereignty, International Relations, and the Third World (New York: Cambridge University Press, 1990).

7 For an explanation of the role of public enterprises (parastatals) in the patrimonial system see, Jean-Franços Bayart, The State in Africa: The Politics of the Belly (New York: Longman, 1993), pp. 75-79. 


\section{From the outside-in}

Africa's post-independence rulers inherited artificial states created as a compromise among the European colonial powers at the Berlin conference of 1885; most revealingly about $45 \%$ of all African boundaries are straight lines that either correspond to an astrological measurement or are parallel to some other set of straight lines. The first cohort of post-independent African rulers accepted these borders and agreed to what was in effect a patrimonial pact among themselves at the founding of the OAU. During the Cold War, while the U.S. and the U.S.S.R. supported proxy wars within the borders of these states, they were nonetheless careful to limit cross-border conflict. In extreme cases, the superpowers pumped resources into the corrupt patrimonial governments in return for their political support, and in many cases this support was the lifeblood of these regimes. With the end of the Cold War, this support was sometimes suddenly withdrawn further weakening the quasi-state.

The penumbras of these weak states have been described by Christopher Clapham as "no man lands." ${ }^{8}$ Pre-colonial Sub Saharan African states never had the insentives to subdue their hinterlands. ${ }^{9}$ This is because, low population densities (dispersed across large hinterlands) made it difficult to tax individuals or to derive rents from agriculture. By focusing on controlling the administrative and coercive apparatus located in the colonial capital, colonial rule did little to help the state project authority. The post-colonial state inherited these weaknesses and then made them worse. Its political system typically favored urban elites, or sometimes labor elites, while denigrating the countryside and ignoring the rural population. Most African states transferred the wealth of the rural areas to the urban centers through monopsonistic systems where state marketing boards set producer prices. $^{10}$ Whatever tenuous links there were between the center and periphery were further weakened. ${ }^{11}$ Finally, the fact that newly independent Africa inherited artificial borders that spread single ethnic groups across borders exacerbated the problem. In Jeffrey Herbst's words:

Christopher Clapham, Africa and the International System (New York: Cambridge University Press, 1996).

Jeffery Herbst, States and Power, Comparative Lessons in Authority and Control (Princeton: Princeton University Press, 2000), p. 21; see also Raymond Copson, Africa's Wars and Prospects for Peace (New York: M.E. Sharpe, 1994), p. 94.

10 Robert Bates, Markets and States in Tropical Africa: The Political Basis of Agricultural Policy (Berkeley: University of California Press, 1981).

11 Robert I. Rotberg, "The Failure and Collapse of Nation States: Breakdown, Prevention and Repair," in Robert I. Rotberg, ed. When States Fail (Princeton: Princeton University Press, 2004), p. 7. 
The fundamental problem facing state-builders in Africa - be they precolonial kings, colonial governors, or presidents in the independent era - has been to project authority over inhospitable territories that contain relatively low densities of people. $^{12}$

Over time, and as their patrimonial resources shrank, the rulers had even more difficulty projecting authority into the periphery of their countries, to say nothing of providing public goods. In the case of the DRC, for instance, only 15 percent of the roads inherited from Belgian colonial rule were still passable twentyfive years later. ${ }^{13}$

The combination of weak states and unsecured hinterlands is the cause of state collapse and its spread. The result is borders that literally bleed into each other. The contagion of state collapse has swept across much of West and Central Africa. Liberia has infected much of West Africa. The instability in the DRC spills across its borders into East Africa and it threatens the relatively stable sub-continent of southern Africa. Zimbabwe is in imminent peril.

\section{The classic cases: Liberia and the DRC}

Liberia is a classic case of state collapse in all its dimensions. On December 24, 1989, two hundred or so insurgents led by Charles Taylor, the head of the National Patriotic Front of Liberia (NPFL), crossed from Côte d'Ivoire into Liberia. And although his original purpose may have been to overthrow the Doe regime and capture the statehouse, the insurgency spawned the proliferation of warlord groups (as many as seven by 1997) ${ }^{14}$ who have pillaged the country for years.

Liberia was founded by the American Colonization Society for the resettlement of slaves in the 1820s. It became independent in 1847, and was governed by an oligarchy of American-Liberian elite. The social stratification resembled that of the antebellum South in the United States. ${ }^{15}$ The hinterland of Liberia was seen as inhabited by "tribal people," such as the Mano and Gio in the north, Krahn in the northeast, and Mandingo in the west. Most importantly, the majority of the indigenous people lived in the hinterland. The American-Liberian elite took the land from the indigenous groups and there were, in fact, a series of

12 Herbst, States and Power in Africa, p. 11.

13 William Reno, Warlord Politics, p. 154 cited in John Ayoade, "States Without Citizens," in Donald Rothchild and Naomi Chazan, eds., The Precarious Balance: State and Society in Africa (Boulder: Lynne Rienner Publishers, 1988), p. 106.

14 Stephan Ellis "Liberia's Warlord Insurgency" in Christopher Clapham, ed. African Guerrillas (Bloomington: Indiana University Press, 1998), p. 154.

15 Morten Bøås, "Liberia-the Hellbound Heart? Regime Breakdown and the Deconstruction of Society," Alternatives 22 (1997). 
revolts against the settlers: the Dei Wars (1821-22), the Grebo War (1875), the Gola Wars (1898-99), the Kissi War (1903), the Kru War (1905), the Loma Wars (190507), the Bassa War (1906), the Kpelle War (1911), the Sapo War (1912-19) the Krahn War (1921) and Gio War. Nonetheless, under the True Whig Party, and with the implicit support of the U.S., the American-Liberian elite ruled the country.

In the classic Sub-Sahara Africa scenario, the True Whig Party, representing the American-Liberian elite, had difficulty broadcasting authority into the hinterland. Therefore, under President William Tubman (1944-1971), a type of affirmative action program for the hinterland, called the Unification Policy, was initiated. His successor, William Tolbert (1971-1980), expanded the program to include the military. The Unification Policy backfired. Land deprivation had already peaked by the late 1970 s and the Unification Policy only led to rising expectations, particularly in the military where the non-American-Liberian elite were treated as second class soldiers. On April 12, 1980 Sergeant Samuel Jackson Doe, a Krahn, overthrew the True Whig government of President Tolbert. Over the next decade, Doe eviscerated the state, ethnized the Armed Forces of Liberia $(\mathrm{AFL})^{16}$ and eliminated any remnants of civil society. After a coup attempt on 12 November 1985 led by Thomas G. Quiwonkpa (A Gio), the former Commander General of the Armed Forces of Liberia, the Doe government killed innocent Gio and Mano citizens ${ }^{17}$ - as many as $3000 .^{18}$ Doe and his predecessors thoroughly hollowed out the Liberian state. In Stephen Ellis's words:

Doe used his tenure of government to plunder the countries wealth blatantly and brutally; after the bloody suppression of a coup attempt by his rival Thomas Quiwonkpa in 1985, he resorted to a particularly poisonous from of ethnic manipulation which was to have consequences in the ethnic pogroms of $1990 .^{19}$

With the end of the Cold War Doe could no longer depend on the patronage of the U.S., which was even greater than that given to his predecessor. U.S. aid finally ended in 1988 with Doe's failure to pay $\$ 7$ million in arrears on a military loan. ${ }^{20}$ The International Monetary Fund (IMF) and World Bank followed suite by cutting off access to their funds. All it would take to collapse the state was pressure from the outside.

\footnotetext{
16 Herbert M. Howe, Ambiguous Order: Military Forces in African States (Boulder: Lynne Rienner Publishers, 2001), p. 133.

17 Al-Hassan Conteh, Joseph S. Guannu, Hall Badio, Klaneh W. Bruce, "Liberia," in Adebayo Adedeji, ed. Comprehending and Mastering African Conflicts (New York: Zed Books, 1999), p. 115.

Howe, Ambiguous Order: Military Forces in African States, p. 45.

Ellis, "Liberia's Warlord Insurgency," p. 157.

Reno, Warlord Politics, p. 88.
} 
Charles Taylor used personal ties with heads of state in both Côte d'Ivoire and Burkina Faso to invade and conquer the state. The Liberian conflict continues to be fanned by regional actors: Côte d'Ivoire government officials and associates of Henri Konan Bedie made money from commercial deals with various Liberian factions; ${ }^{21}$ some Côte d'Ivoire officials reportedly owned rubber plantations in NPFL held areas. Senior Guinea officials who made diamond deals with Ulimo-k militia (a break-away rebel group) and Mandingo traders have been linked with Mali and Senegal. ${ }^{22}$ Western observers believe Guinea's Presidential Guard may be involved in smuggling diamonds out of Sierra Leone. ${ }^{23}$

Informal regional dynamics also fueled state collapse. Taylor was able to fund his incursion by crossing into Nimba country in northeast Liberia and thereby capturing resource rich enclaves, in this case beginning but hardly ending with iron ore mines. For instance, Taylor used revenues from the Bong Mining Company to buy arms. ${ }^{24}$ When he needed to, Taylor, through his support for Foday Sankoh and the Revolutionary United Front (RUF) in Sierra Leone, gained access to that country's diamond wealth. What was known as "Taylorland" included parts of neighboring countries and gave Taylor and income from 1990 to 1992 of between \$200 and \$300 million. ${ }^{25}$ And the rich Kono diamond fields are in the hinterland of Sierra Leone, along the border with Guinea. Finally, the collapse of Liberia triggered coups in neighboring countries. For instance, on July 23,1994 Gambian soldiers in ECOMOG (the Nigerian led regional peacekeeping force) that was meant to stabilize war-torn West Africa, overthrew President Sir Dawda Jawara.

The DRC followed a similar pattern and threatens to spillover into southern Africa. In May 1997, the Alliance of Democratic Forces for the Liberation of Congo/Zaire (ADFL), led by the ex-Marxist Laurent Desire Kabila, entered the capital city of Kinshasa. The ADFL marched east, from South Kivu Province, clear across the vast expanse of Zaire. (DRC).

The DRC is a classic case of state collapse. After the colonial rule and pillage of Zaire by King Leopold of Belgium, Mobutu Sese Seko ruled from 1965 until 1997. Mobutu's rise to power, and then his fall from power, were both partially due to the inability of the African state to project authority out to the periphery of the state. He

Ellis, "Liberia's Warlord Insurgency," p. 164.

Ibid.

Howe, Ambiguous Order: Military Forces in African States, p. 45.

Reno, Warlord Politics, p. 95.

William Reno, "How Sovereignty Matters: International Markets and the Political Economy of Local Politics in Weak States," in Thomas Callaghy, Ronald Kassimir, Robert Latham, eds. Intervention and Transnationalism in Africa: Global-Local Networks of Power (New York: Cambridge University Press, 2002), p. 202. 
came to power in the wake of secessionist pressures in the periphery - Katanga, and was forced out of power by the ADFL, which marched to Kinshasa from the same area.

Mobutu developed the classic patrimonial state (often in this case called a kleptocracy). ${ }^{26}$ It was purposefully and deeply anti-bureaucratic. Mobutu used the military to control both the country's mineral wealth (the fountainhead of his patronage system based in Kinshasa ${ }^{27}$ and to control the separatist pressures that could deny him that wealth. ${ }^{28}$ Mobutu also used classic divide and rule techniques; he fostered and manipulated conflicts within local communities so that local strongmen would have to appeal for his personal assistance. One example stands out for its later repercussions. In 1981, Zaire passed a new citizenship rule concerning the Banyarwanda (Tutsi) living in the North Kivu area of eastern Zaire. The Banyarwanda trace their heritage back to Rwanda, some were included in Zaire by the colonial partition of the Kingdom of Rwanda while others later migrated to Zaire. Without going into detail, after the Banyarwanda in eastern Zaire were threatened with statelessness, they became a central part of the anti-Mobutu insurgency. ${ }^{29}$

As rich as Zaire was in mineral resources, Mobutu depended on external assistance, in particular from the U.S., to maintain his patronage network. The end of the Cold War was the beginning of his demise. The level of bilateral aid to Zaire went from $\$ 823$ million in 1990 to $\$ 178$ in $1993 .^{30}$ Also, the International Monetary Fund and World Bank were no longer as willing to engage in the "ritual dance of debt relief" with Mobutu. In fact, Nicolas van de Walle argues that Zaire was one of the few African states that suffered a decline in aid after the Cold War. ${ }^{31}$

As with the Liberia's Unification Policy, Mobutu tried to stem the tide of change with internal reforms. In April 1990, Mobutu announced the end of the Second Republic. This ushered in a period of "liberalization," which, as did glasnot and peristroka in the former USSR, only served to weaken the state.

Thus Zaire was hollowed-out over the long rule of Mobutu. But the collapse of Zaire (DRC) actually begins with the Tutsi Rwandan Patriotic Front's (RPF)

\footnotetext{
26 Thomas Callaghy, The State-Society Struggle: Zaire in Comparative Perspective (New York: Columbia University Press, 1984).

27 William C. Reed, "Guerrillas in the Midst: The Former Government of Rwanda and the Alliance of Democratic Forces for the Liberation of Congo-Zaire in Eastern Zaire," in Clapham, ed. African Guerrillas, p. 153.

$28 \quad$ Michael Klare, Resource Wars (New York: Henry Holt and Company, 2001), p. 209.

29 Reed, "Guerrillas in the Midst," p. 143.

30 Reno, "How Sovereignty Matters," p. 200.

31 Nicolas van de Walle, "The Economic Correlates of State Failure," in Rotberg, ed. When States Fail, p. 209.

31 Reed, "Guerrillas in the Midst," p. 136.
} 
invasion of Rwanda from Uganda. When the RPF advanced to Kigali in July 1994, after the genocide, virtually the entire Hutu government fled to Zaire, forming the Former Government of Rwanda (FGOR). Their command structure and key troops were left virtually in place. ${ }^{32}$ Pressure from the FGOR and the Zairean Armed Forces (ZAF) caused the Banyamulenge in Zaire's South Kivu province (led by Kabila) to strike back, and with the aid of Uganda and Rwanda, advance toward Kinshasa. ${ }^{33}$ Kabila, who had carved out a niche among the Bembe in Eastern Zaire, got a jump-start by capturing mineral rich areas in Zaire's hinterland. And as Reno notes, once he appeared successful, he had no trouble gaining commercial partners, just as Taylor had done in Liberia. ${ }^{34}$ As noted above, Zaire had always struggled with the mineral rich areas in its periphery: Shaba (Katanga), rich in copper; Eastern Zaire, gold, coltan, and agriculture; and East Kasai, industrial diamonds. The last of these had even established an independent monetary system and its own university.

As with Liberia, the role of regional actors did not end with the overthrow of the regime. Uganda and Rwanda turned against Kabila, because they wanted a buffer between themselves and the Interahamwe (Hutu militia along their borders) and ex-Mobutu forces. Laurent Kabila and his successor, Joseph Kabila, responded to the threat from Uganda and Rwanda by allying with Zimbabwe, Angola, Nambia, Chad, and Sudan. In most of these cases, this alliance took the form of transnational patrimonial networks feeding off and fueling the insurgencies and counterinsurgencies in the DRC's periphery.

The transborder nature of the DRC collapse is even more complex than Liberia's, possibly because of its geographical position - it borders on nine states. In August 1998, fighting erupted again. This time, Rwanda and Uganda supported different factions, each trying to protect its northwest frontier with the DRC. By mid-1999, rebel movements controlled one third of the DRC, and the rebel movement, Rassemblement Congolais pour la Démocratie (RCD), had split into three groups. ${ }^{35}$ The FGOR formed an alliance with Hutu militia in Burundi. As stated above, Uganda and Rwanda had proxies in the DRC.

Profit, not necessarily territorial gain, is the motive. The quadrangle comprising Uganda, Rwanda, Burundi, and Congo, has four major trading routes. The first carried agricultural and manufactured goods between Kampala and Bukavu (DRC); the second is for goods and people between the port-city of Bujumbura in

33 For a thorough chronology of these events see Reed, "Guerrillas in the Midst," pp. 140-144.

$34 \quad$ Reno, Warlord Politics, p. 174.

35 Thomas Callaghy, Ronald Kassimir, Robert Latham, "Introduction: Transboundary Formations, Intervention, Order, and Authority," in Intervention \& Transnationalism in Africa, p. 3. 
Burundi and the port of Uvira (DRC); the third moves between the Oriental Province of Congo directly to Uganda; and the fourth crosses Lake Tanganyika to port towns of Kalemie in Congo and Kigoma in Tanzania and between Lubumbashi in Congo and Dar-es-Salaam, via Kapiri Mposhi in Zambia. The collapse of the DRC has allowed neighboring countries to control much of this trade, even as it originates in the DRC. The Uganda backed Rassenblement Congolais pour la Démocratie (RCD) have control over much of the gold and coffee producing areas of Eastern Zaire. The Rwandan backed Rassemblement Congolais pour la Démocratie (RCD), while not in control of vast mineral resources, collect fees from local producers and Lebanese intermediaries, and control much of Kisangani's palm oil business, which is exported to Kigali via military planes. Finally, Rwanda and its RCD allies have resorted to twinning Congolese and Rwandan cities, and Rwanda plans to set up an export processing zone along the DRC border.

In both the cases of Liberia and the DRC, insurgencies that started in the periphery relatively quickly captured the capital; in both cases, they left the shell of a state in their wake and anarchy in the peripheries. In both cases, the remnants of various armies have fractured into warlord armies: in Liberia, the Independent National Patriotic Front of Liberia (INPFL) led by Prince Yourmie Johnson split off from Taylor's NPFL, and the ex-Liberian army split into factions. In 1990, many Krahns and Mandingos fled to Sierra Leone and Guinea to form the United Liberation Movement for Democracy (Ulimo). Originally supported by a united Uganda-Rwanda front, in June 1999, the rebel movement in the DRC split into three groups. And, in fact, the Uganda and Rwanda backed forces battled each other deep inside the DRC. There are also, as in the case with Liberia, various militia fighting in the DRC, one led by a former Congolese businessman with backing from Uganda.

What does all this tell us about Zimbabwe's future?

\section{Zimbabwe's road to perdition}

Strong states control their territory and provide public goods. Zimbabwe can only do the former. Nonetheless, on the surface, Zimbabwe is a much different story than either Liberia or the DRC. The process of colonization and decolonization actually created a relatively strong state. In fact as Herbst relates, "... the extraordinary repression that Robert Mugabe's government visited on Matabeleland (in southwest Zimbabwe) in 1983 and 1984 ..." was partially possible due to "... the relatively good infrastructure that had been inherited from Rhodesians." ${ }^{36}$ This included the infamous North Korean-trained Fifth Brigade, which ravished Matabeleland in southwest Zimbabwe between 1982 and 1984,

$36 \quad$ Herbst, States and Power, p. 169. 
home to the minority ethnic Ndebele who had supported Mugabe's rival, Joshua Nkoma. Up to 10,000 civilians were killed. ${ }^{37}$ However, Mugabe, like Tubman, Doe, and Taylor in Liberia and Mobutu in Zaire, has created a corrupt patrimonial system that has systematically hollowed out the Zimbabwean state. This is no mean achievement for a state that was born in 1980 as Sub-Sahara Africa's second most industrialized. Politically, Mugabe has ruled atop a one party state for almost two decades. Political and institutional decay has accelerated in the last few years as he has made sure the Supreme Court was compliant, rigged elections, and jailed opponents. But as Robert Rotberg has argued, it is the convergence of economic and political decay that signals imminent collapse. ${ }^{38}$ The economy is in ruin.

The 2004 tobacco crop, Zimbabwe's prime export (accounting for 30\% of foreign earning), is projected to be $45.5 \%$ lower than the previous year. ${ }^{39}$ And the year before was not very good. Agricultural production in general has steadily declined since Mugabe's government sanctioned land seizure beginning in 2000. Of the people who got good arable land, 99.2 percent are cabinet ministers, wives, political cronies, relatives, and girlfriends of the Mugabe administration. ${ }^{40}$ The UN World Food Program estimates that 5.5 million Zimbabweans will face acute shortages of food, almost half the population. ${ }^{41}$ Other parts of the economy have been affected by the decaying state. In the spring of 2003, there were mass job "stayaways" and in April the Zimbabwe Congress of Trade Unions staged labor action. There are shortages of fuel, electricity, and cash. Unemployment is at about $75 \%$, and inflation is expected to reach $1000 \% .{ }^{42}$ The health care system, once along with South Africa's by far the best in Africa, is in disarray - fewer than 900 doctors remain in a country of 11.6 million, one for every 13,500 people. $^{43}$ Meanwhile, prior to the last election, Mugabe purchased 19 expensively armored limousines and he is putting the finishing touches on a 130,000 square foot palace north Harare for about nine million (US) dollars. ${ }^{44}$ But, the political nature of the

37 U.S. Institute for Peace, "Zimbabwe and the Prospects for Nonviolent Change," Special Report 109 (August 2003), p. 3.

38 Robert Rotberg, "Failed States in a World of Terror," Foreign Affairs 81 (2002), p. 129.

39 Zimbabwe Standard (Harare), 22 September 2003. "Drastic Plunge in Tobacco Output," Kumbirai Mafunda.

$40 \quad$ New York Times, 19 October 2003, "Corruption and Despair are Choking Zimbabwe," Michael Wines.

$41 \quad$ Zimbabwe Standard (Harare), 22 September 2003. "Bleak Prospects for Agriculture Recovery," Caiphas Chimhete.

$42 \quad$ U.S. Institute for Peace, "Zimbabwe and the Prospects for Nonviolent Change," p. 5 New York Times, 5 February 2004. "With Health Systems in Tattters, Zimbabwe Stands Defenseless," Michael Wines.

$44 \quad$ New York Times, 19 October 2003, "Corruption and Despair are Choking Zimbabwe," Michael Wines. 
Zimbabwean patrimonial system is an African anomaly - and this is the key to understanding the threat of state collapse there. While most post-independent African rulers got their support from an urban elite, Mugabe has depended on strong support from the countryside and his ex-comrades in arms. The opposition, the Movement for Democratic Change (MDC) dominates the urban centers of Zimbabwe, as did earlier challenges to ZANU rule by the Zimbabwe Unity Movement in 1990 and by the Forum Party in 1995. Mugabe's regime has responded by using the land issue to shore up its rural base and to reward cronies, particularly military leaders. Mugabe also established a national youth training program in 2001, know as the "green bombers"; they serve as an informal party militia. Like the RUF in Sierra Leone, they enlist children soldiers and hold women in the Youth Service camps as sexual servants. ${ }^{45}$

The risk of state failure in Zimbabwe, nonetheless, is not from the perpetuation of ZANU-PF rule, but the displacement of one patrimonial system with another, similar to what happened in Zambia. When the Zambian labor leader Frederick Chiluba was elected in 1991 as leader of the Movement for Multiparty Democracy (MMD), a new era of democracy and development was proclaimed. Instead, Chiluba ruled much as had his predecessor, Kenneth Kaunda, who had headed the one party state since Zambian independence in 1964. Chiluba even jailed Kaunda and nine other members of his party, the United National Independence Party (UNIP). After a coup attempt in 1997, the government declared a 90-day state of emergency.

The greater threat to Zimbabwe would be if the MDC becomes the ruling party and systematically dismantles the old patron client system and replaces it with one of its own making. This, of course, does not have to happen. But, if the transition is not closely monitored, Zimbabwe would tragically come to resemble Liberia, where an elite has control over the urban area(s), and well armed disgruntled factions patrol the periphery. There has already been violence between ZANU and the MDC and more than a hundred have died in the last three years and thousands seriously injured. In fact, after their success in parliamentary elections in 2003, rural areas were no-go for the MDC. ${ }^{46}$

As with Liberia and the DRC there is a regional dimension. Although Mozambique has been at peace, there would be opportunities for ex-ZANU soldiers and militia to join forces with the remnants of Mozambique rebels, even with ones they once fought, as is common in Liberia. The illicit business ties between Kabila's

\footnotetext{
45 New York Times, "Reports of Rape and Torture Inside Zimbabwe," 28 December 2003, Michael Wines.

$46 \quad$ U.S. Institute for Peace, "Zimbabwe and the Prospects for Nonviolent Change," p. 7.
} 
regime in the DRC and Mugabe's cronies - a sort of trans-patrimonial alliance - is more serious. ${ }^{47}$ Criminal groups in Zimbabwe, ${ }^{48}$ along with Zambia and South Africa, have developed the most extensive networks in southern Africa. ${ }^{49}$ Among the powerful Zimbabweans mentioned in a UN report on the illegal exploitation of natural resources in the DRC are: Speaker of the Zimbabwean Parliament Emmerson Mnangagwa, Zimbabwean Defense Force commander General Vitalis Zvinavashe, and Defense Minister Sidney Sekeramayi. ${ }^{50}$ The DRC-Zimbabwean network has also been accused of supporting armed groups opposed to Rwanda and Burundi. If driven from power, the remnants of Mugabe's regime would have ready made networks to fund insurgencies. As well, there would be opportunities to link with transnational criminal organizations (TCOs) in South Africa. Groups of thugs know as Akaplas, which are made up of remnants of ex-anti apartheid combatants who could not or would not be assimilated by the post-apartheid South African Defense forces, have formed TCOs within South Africa. ${ }^{51}$

Finally, if the MDC were to come to power, intra-party factionalism and competition within the ZANU-PF, such as between the Zezuru and Karanga factions, could become violent and each would be well funded. ${ }^{52}$ The point is that just as in Liberia and the DRC, fracturing along ethno-linguistic groups could further fuel state collapse and warlord conflict. For instance, the veterans who participated in the farm occupations were mainly ex-ZANLA forces who were attached to Mugabe's ZANU. Ex-ZIPRA soldiers who were attached to Joshua Nkoma's ZAPU were opposed to forceful farm occupations. ${ }^{53}$ Not only does the resentment over Fifth Brigade's actions in Matabeleland between 1982 and 1984 create a volatile situation, but the structure of Zimbabwe's demobilization program after

$47 \quad$ See, Michael Nest, "Ambitions, Profits and Loss: Zimbabwean Economic Involvement in the Democratic Republic of the Congo," African Affairs 100 (2001).

48 On crime and human security in Zimbwbe see, Charles Goredema, "Zimbabwe and Beyond Declarations of Intent: Transnational Crime Initiatives and Legislative Reform in Zimbabwe," African Security Review Vol. 10, No. 3 (2001). http://222.iss.co.za/Pubs/ION3/Gordema.html.

49 Peter Gastrow, "The SADC Region: A Common Market for Criminals," African $\begin{array}{lllllll}\text { Security } & \text { Review } & \text { Vol. } & 10 & \text { No. } & 4 & \text { (2001). }\end{array}$ http://www.zwnews.com/issuefull.cfm?ArticleID+6785.

$50 \quad$ Sunday Times (Johannesburg), 18 May 2003. "Zimbabwean elite 'looted DRC'." See also, "Gunning for Mnangagwa," Africa Confidential 16 April 2004, Vol. 45, No. 8, p. 1.

$51 \quad$ Gary Kynoch, "The 'Transformation' of the South Africa Military," The Journal of Modern African Studies 34 (1996), p. 456.

$52 \quad$ See, Chris Maroleng, "Fiddling While Zimbabwe Burns," Situation Report (Pretoria: Institute for Security Studies, 13 October 2003).

53 Tony Addison, "Conflict in Zimbabwe: The Political and Economic Determinants," paper prepared for the UNU/WIDER project meeting on 'Why Some Countries Avoid Conflict While Other Fail'. Helsinki, 20-21 October, 2000, p. 10. 
independence in 1980 may make it worse. The demobilization program did not sever ties between ex-combatants and their wartime military factions (because of deep-seeded mistrust between ZIPRA and ZANLA); ZIPRA and ZANLA forces were assembled and encamped apart from one another. ${ }^{54}$ Finally, the militarized and brutalized youth groups, as they have in West Africa, would further fuel the conflict.

\section{Lessons not learned}

The lessons of state collapse in West and Central Africa and the threat to Zimbabwe are complex, but the international community's response has been simplistic. There has been too much focus on stitching together vagabond governments in the capitals of collapsed states to displace the disgraced or defeated regimes. For instance, the internationally brokered plan for Liberia in the wake of Taylor's abdication and retreat to Nigeria is essentially a patrimonial bargain among warring factions, including two rebel groups. Each group has inherited portfolios in the new government that translates into control of state generated rents. As these groups become less satisfied with their share of the bounty, they can return to their origins in the periphery. A similar bargain was made in Sierra Leone, which had a disastrous result.

A long historical process, almost a "perfect storm," that transcends the colonial and post-colonial eras has created weak African states that have no immune systems to protect them from the contagion of states collapse in contiguous states. Côte d'Ivoire is a stunning and cautionary tale. In 1998, three respected experts on Africa, David Gordan, David Miller and Howard Wolpe could state: "By contrast [to Liberia and the DRC], neighboring Côte d'Ivoire boasts a strong state with a vibrant private sector and one of the most modern and cosmopolitan capitals in Africa." ${ }^{55}$ Civil war, a least partly due to the Ivorian government's crack down on immigrants from other West African nations, has made it look more like its neighbors than the standard bearer for stability. In fact, rebel groups from near the Liberian border are closely mimicking the methods of its neighboring states' rebel movements. In November 2003, youth belonging to militias known as "Young Patriots" demonstrated outside a French military base, and threw stones at French soldiers demanding the 4,000 French peacekeepers patrolling the zone between the government and rebel forces in the North leave. In the wake of civil war, cocoa production (its key export) is down, farmers may be abandoning land, and cross-

\footnotetext{
54 Michael Westphal, "Critical Factors in Demobilization, Demilitarization and Reintegration: An Analysis of Ethiopia, Liberia, Mozambique and Zimbabwe." Prepared for: Office of the Secretary of Defense International Security Affairs, Office of African Affairs, OSD/ISA/AFR, February 2002, p. 57.

55 David, Gordan, David Miller, Howard Wolpe, The United States and Africa: A PostCold War Perspective (New York: W.W. Norton, 1998), p. 51.
} 
border smuggling is on the rise. Again, the lesson is that a new government in the capital will do little to fix the problem. The problem is usually hundreds of miles away.

Fixing the states of Sub-Sahara Africa will entail fixing the regions. Conflict continues to come from the outside-in. In fact, in an ironic historical twist, the inability of pre-colonial African states to broadcast authority into the periphery was partially because the land was not valuable. Today, the portable wealth of the peripheries coupled with its exploding population growth (caused by refugee movements) is fueling the conflicts. This means focusing as much attention of the outside-in causes of collapse as on the inside-out causes. It means a reallocation of resources, including regional peacekeeping and UN peacekeeping forces to the periphery. It means paying attention to the cross border networks that continue to make the penumbras of these weak states no man lands, and that continue to be the fountainheads of insurgency and instability. Finally, it means ending three eras of exclusive state building form the inside-out. 